University of Pennsylvania Carey Law School

Penn Law: Legal Scholarship Repository

Faculty Scholarship at Penn Law

$1-1-2011$

\title{
Are We Responsible for Who We Are? The Challenge for Criminal \\ Law Theory in the Defenses of Coercive Indoctrination and "Rotten Social Background"
}

Paul H. Robinson

University of Pennsylvania Carey Law School

Follow this and additional works at: https://scholarship.law.upenn.edu/faculty_scholarship

Part of the Criminal Law Commons, Criminology Commons, Family, Life Course, and Society

Commons, Inequality and Stratification Commons, Law and Society Commons, Place and Environment

Commons, and the Social Psychology Commons

\section{Repository Citation}

Robinson, Paul H., "Are We Responsible for Who We Are? The Challenge for Criminal Law Theory in the Defenses of Coercive Indoctrination and "Rotten Social Background"' (2011). Faculty Scholarship at Penn Law. 349.

https://scholarship.law.upenn.edu/faculty_scholarship/349

This Article is brought to you for free and open access by Penn Law: Legal Scholarship Repository. It has been accepted for inclusion in Faculty Scholarship at Penn Law by an authorized administrator of Penn Law: Legal Scholarship Repository. For more information, please contact PennlawIR@law.upenn.edu. 


\title{
Are We Responsible For Who We ARE? The Challenge for CRIMINAL LAW TheORY IN THE DEFENSES OF COERCIVE INDOCTRINATION AND "ROTTEN SOCIAL BACKGROUND”
}

\author{
Paul H. Robinson ${ }^{*}$
}

\begin{abstract}
Should coercive indoctrination or "rotten social background" be a defense to crime? Traditional desert-based excuse theory roundly rejects these defenses because the offender lacks cognitive or control dysfunction at the time of the offense. The standard coercive crime-control strategies of optimizing general deterrence or incapacitation of the dangerous similarly reject such defenses. Recognition of such defenses would tend to undermine, perhaps quite seriously, deterrence and incapacitation goals. Finally, the normative crime-control principle of empirical desert might support such an excuse, but only if the community's shared intuitions of justice support it. The law's rejection of such defenses suggests that there might be little popular support for them.

This is not necessarily the end of the story, however. Coercive indoctrination has in some cases, such as that of POW Richard Tenneson, prompted considerable public sympathy, confirming that lay persons do tend to exculpate some such offenders. Such intuitive support for a coercive indoctrination defense suggests that there may be practical crimecontrol value in having the criminal law recognize it. If the criminal law can build its reputation as a reliable moral authority with the community it governs, it can harness the potentially powerful forces of social and normative influence.

There are good arguments for seeing "rotten social background" as a form of coercive indoctrination and, thus, for considering it too for a defense under such a newly-created doctrine. However, while the two defenses may be analogous, having a "rotten social background" by itself is not likely to meet the minimum prerequisites that logically would adhere to a coercive indoctrination defense, and certainly would have little intuitive support. On the other hand, specific cases of "rotten social background"

\footnotetext{
* Colin S. Diver Professor of Law, University of Pennsylvania Law School. The author thanks Sean Jackowitz, University of Pennsylvania Law School Class of 2012, for his very useful research assistance.
} 
might well qualify, if it is shown that that experience forced upon the person a set of beliefs and values compelling him toward the offence that he could not reasonably have been expected to resist.

I. TRADITIONAL EXCUSE THEORY AND THE INADEQUACY OF A "BUT FOR" CAUSE AS AN EXCUSE: JUDGE BAZELON IN BRAWNER AND ALEXANDER .............................................. 55

II. COERCIVE INDOCTRINATION \& "ROTTEN SOCIAL BACKGROUND" UNDER COERCIVE CRIME CONTROL: DETERRENCE OR INCAPACITATION AS DISTRIBUTIVE PRINCIPLES ................... 61

III. EMPIRICAL DESERT AS A DISTRIBUTIVE PRINCIPLE: NORMATIVE CRIME CONTROL ............................................ 62

IV. COERCIVE INDOCTRINATION UNDER NORMATIVE CRIME CONTROL: THE CASE OF POW RICHARD TENNESON

V. TESTING THE LIMITS OF A COERCIVE INDOCTRINATION OR A “ROTTEN

Social BaCKGRound” EXCuSE: THE CASE OF Alex Cabarga ... 69

VI. "ROTTEN SOCIAL BACKGROUND" \& EMPIRICAL DESERT .......... 74

VII. SUMMARY AND CONCLUSION .................................. 76

Should "rotten social background" (RSB) be a defense to crime? To telegraph my conclusions, there seems little doubt that traditional excuse theory would suggest that it ought not be. Even more clearly, the modern coercive crime-control doctrines of general deterrence and incapacitation would not support an excuse in such cases. On the contrary, persons whose RSB incline them toward crime would be special targets for deterrent threats and incapacitative control by the criminal justice system. Normative crime control, under a distributive principle of empirical desert, in contrast, is less clear in its rejection of an RSB defense. Its view would depend upon whether there is community support for seeing an RSB as an excuse, which there may not be.

Perhaps the best chance for an RSB excuse is in those cases where a child's development is under conditions that inevitably normalize the child to see violence and deceit as acceptable and indeed necessary methods of negotiating the challenges of daily life. One could argue that such conditions are analogous to a process of coercive indoctrination (CI) and can render an offender blameless under an argument analogous to that supporting a $\mathrm{CI}$ excuse.

What I mean by "coercive indoctrination" $(\mathrm{CI})$ is changing a person's values or beliefs through coercive means. ${ }^{1}$ Thus, a defendant who would

1. As Richard Delgado describes the concept: The victim of [coercive indoctrination] typically commits criminal acts fully aware of their wrongfulness. He acts consciously, even enthusiastically, and without overt coercion. Yet, in an important sense, the guilty mind with which he acts is not his own. Rather, his men- 
not have committed the offense in question were he the "old self" might claim that he should get a defense since he acted only because of new beliefs and values, forcibly imposed on him, for which he ought not be held accountable.

One could view "rotten social background" as a specialized form of CI. That is, one might argue that the offender's "rotten social background"-for example, growing up in a world of deprivation and violence-induced beliefs and values that inevitably caused the offense, and that the offender would not have committed but for his RSB. ${ }^{2}$

Parts I through III consider RSB under each of the alternative distributive principles that one might used in assessing criminal liability and punishment: deontological desert and its traditional excuse theory, the coercive crime-control doctrines of deterrence and incapacitation, and the normative crime-control principle of empirical desert. The remaining parts, Parts IV through VI, consider the arguments that might support an excuse for coercive indoctrination, and how some cases of "rotten social background" might be part of that excuse.

\section{TRADITIONAL EXCUSE THEORY AND THE INADEQUACY OF A "BUT FOR" CAUSE AS AN EXCUSE: JUDGE BAZELON IN BRAWNER AND ALEXANDER}

Traditional excuse theory, reflected in the excuses of essentially all American jurisdictions, provides an excuse upon the satisfaction of two requirements: (a) a disability must cause (b) a recognized excusing condition. $^{3}$ In the excuses of insanity and involuntary intoxication, for example,

tal state is more appropriately ascribed to the captors who instilled it in him for their own purposes.

Richard Delgado, Ascription of Criminal States of Mind: Toward a Defense Theory for the Coercively Persuaded ("Brainwashed") Defendant, 63 MiNN. L. REv. 1, 11 (1978) (footnotes omitted).

2. In fact, Joshua Dressler argues that RSB cases are morally indistinguishable from archetypal "brainwashing" cases.

[Delgado] would excuse a defendant who is the victim of "abnormal influences," such as physical depletion, prolonged isolation, and interrogation, but would deny the defense to a person who presents some of the same symptoms of choice reduction, but whose symptoms are not the result of abnormal influences. Conditions such as life-long poverty, drug addition, a broken home, peer group pressure, and lowered self-esteem might demonstrate that a ghetto inhabitant's choice in committing a criminal act was also substantially reduced....

Joshua Dressler, Professor Delgado's “Brainwashing" Defense: Courting a Determinist Legal System, 63 MINN. L. REV. 335, 358 (1979) (footnotes omitted). Delgado proposed a defense that required inter alia that "[t]he defendant's mental state results from unusual or abnormal influences," that "[t]he criminal acts benefit the captors," and that "It]he actor evidences symptoms typical of the coercively persuaded personality." See Delgado, supra note 1, at 19-22. These requirements would tend to exclude defendants relying on a RSB form of the CI defense. Nevertheless, Delgado has written in support of a RSB defense using similar logic. See Delgado infra note 14.

3. See Paul H. Robinson, A System of Excuses: How Criminal Law's Excuse Defenses Do, and Don't, Work Together to Exculpate Blameless (and Only Blameless) Offenders, 42 TEX. TECH L. REV. 
(a) a mental disease or defect or involuntary intoxication must cause (b) the offender at the time of the offense to suffer sufficient cognitive or control dysfunction so as to be unable to sufficiently understand or control his offense conduct. ${ }^{4}$ The first element, of a disability, requires a real world abnormality or dysfunction. The second element, of a resulting excusing condition, requires a normative judgment that the extent of the dysfunction is sufficiently severe to render the offender blameless for his offense conduct. To give another example, the duress excuse requires that the offender (a) committed the offense under the effects of duress or coercion and (b) that the coercion, in the words of the Model Penal Code, was such that "a person of reasonable firmness in [the offender's] situation would have been unable to resist."

It is obviously inadequate for a defense to show simply that the offender was acting under some coercion or had some mental illness or was involuntary intoxicated to some extent. An excuse is merited only if the extent of the dysfunction meets a critical level: such that the actor could not reasonably have been expected to have remained law-abiding. This is true even if the disability is a "but for" cause of the offense. The offender who steals perfume from the department store because his girlfriend threatens to break up with him if he does not, may well be able to claim that he would not have committed the offense but for the coercion, yet no one would seriously consider that the effect of the coercion was sufficient to merit an excuse. The same is true of the man who is involuntarily intoxicated by his friends and, in that state, has nonconsensual intercourse with a semi-conscious coed. He may well be able to honestly claim that he would not have committed the offense conduct but for his involuntary intoxication, but whether he is entitled to an excuse requires us to know more about the actual effects of the involuntary intoxication on him at the time of the offense conduct. ${ }^{6}$ Was the effect simply a pleasant buzz and a

259,263 (2009) (“The disability requirement consists of some objectively confirmable, real-world abnormality. The excusing condition requirement consists of a particular effect from a disability operating on the actor at the time of his conduct constituting the offense.") (footnotes omitted).

4. See Model Penal CODE $§ 2.08$ (4) ("Intoxication that (a) is not self-induced or (b) is pathological is an affirmative defense if by reason of such intoxication the actor at the time of his conduct lacks substantial capacity either to appreciate its criminality [wrongfulness] or to conform his conduct to the requirements of law."); Id. at $\$ 4.01$ (1) ("A person is not responsible for criminal conduct if at the time of such conduct as a result of mental disease or defect he lacks substantial capacity either to appreciate the criminality [wrongfulness] of his conduct or to conform his conduct to the requirements of law.").

5. Id. $\S 2.09(1)$.

6. In State v. Mriglot, for example, the defendant sought an instruction on involuntary intoxication as a defense to his forgery conviction, which would excuse him if the jury found that he had been "involuntarily under the influence [of] or affected by the use of liquor or drugs." 550 P.2d 17, 17-18 (Wash. Ct. App. 1976) (emphasis added). The court rejected the defendant's instruction. Even if the defendant would not have committed the offense but for the involuntary intoxication, the court concluded, he would have no defense unless the involuntary intoxication caused sufficient dysfunction to render him blameless for the offense. 
minor loosening of restraints? Could we have reasonably expected him to have avoided the offense conduct despite the involuntary intoxication? Even if the offender would not have committed the offense but for the disability, he does not necessarily merit an excuse. The extent of the dysfunction-the extent of cognitive or control impairment-must be shown to have been sufficiently severe as to render him blameless for his offense conduct.

Judge Bazelon's support of the Durham "product test" for insanity stands in direct conflict with these standard requirements for modern excuses. Judge Bazelon sought to leave off the second element for an excuse, the requirement that the disability (such as mental disease or defect) cause a sufficiently dysfunctional effect so as to render the offender blameless for his offense conduct. He argued for an excuse upon a showing of a disability-upon a showing that the offender was mentally ill and would not have committed the offense if he were not,-without inquiring into the extent of the dysfunction or the extent of its effect in causing the offense. By dispensing with the excusing condition requirement, Judge Bazelon's theory of excuses would seem to provide a defense to the mildly coerced thief and the involuntarily intoxicated rapist noted above, a difficult position to sustain.

In United States v. Brawner, the D.C. Circuit rejected Judge Bazelon's Durham arguments, for predictable reasons similar to those above explaining the importance of the excusing condition requirement. ${ }^{8}$ The blamelessness driving an excuse defense does not derive from the bare existence of an actor's disability or even from the fact that the disability may influence the actor toward the violation. The conclusion of blamelessness comes from the existence of the excusing condition-the finding that the effect of the disability on the actor was so severe that we could not reasonably have expected to him to have remained law-abiding. In control dysfunction cases, this requires a finding that the actor made enough of an effort to resist the temptation or compulsion. In cognitive dysfunction cases, it requires that the actor was sufficiently confused in his thinking, and therefore unsure about the nature or legality of his conduct, that he is not to be blamed for the violation. Yet it was this central excusing condition element that Judge Bazelon sought to dispense with in his proposed, and rejected, "product test" for insanity.

This same error propels Judge Bazelon's judgment in United States $v$. Alexander, in which "rotten social background," rather than mental ill-

7. See Durham v. United States, 214 F2d 862, 874-75 (D.C. Cir. 1954) overruled by United States v. Brawner, 471 F2d 969,973 (D.C. Cir. 1972).

8. See 471 F.2d at $977-79$ (noting that "the Durham rule opened the door to "trial by label' " and led to the "tendency of the expert to use concepts [which] can become slogans, hiding facts and representing nothing more than the [expert] witness's own conclusion about the defendant's criminal responsibility.") (internal citation omitted). 
ness, was said to have caused the offender's offense conduct. ${ }^{9}$ A group of unarmed marines in their dress white uniforms had stopped at a hamburger shop with a girlfriend after a celebration of their near-completion of officer basic training. ${ }^{10}$ Alexander began staring at the marines, and when one of the marines returned the stare, Alexander approached and confronted the marines, leaning in and poking one in his name tag, calling them to come outside. ${ }^{11}$ When words were exchanged, Alexander and codefendant Murdock each pulled a handgun and began firing into the group, killing two of the marines. ${ }^{12}$

Murdock's claim was that he should be excused because his RSB had caused his offense conduct. ${ }^{13}$ This is similarly the thrust of Richard Delgado's rationale for a RSB excuse.

An environment of extreme poverty and deprivation creates in individuals a propensity to commit crimes. In some cases, a defendant's impoverished background so greatly determines his or her criminal behavior that we feel it unfair to punish the individual. . . [B]lame is inappropriate when a defendant's criminal behavior is caused by extrinsic factors beyond his or her control. ${ }^{14}$

There is good evidence that an RSB can have potentially quite powerful effects. Murdock grew up nearly penniless in the violent, chaotic Watts section of Los Angeles. He was not responsible for being born into the situation. He had no obvious or easy means of escaping from it. On the other hand, not all people who grow up in such circumstances become violent criminals. That is, even admitting that environment can seriously influence the development of personality, the strength of that influence to committing the offense at hand is at best unclear. But most importantly, even if it could be shown that Alexander's RSB was a but-for cause of his shooting the marines, such a but-for cause by itself is insufficient for excuse, just as it is in the insanity (or duress or involuntary intoxication) situation. To qualify for a defense under traditional excuse theory, Alex-

9. See 471 F.2d 923, 959 (D.C. Cir. 1973) (Counsel "conceded to the jury that Murdock 'did not have a mental disease in the classic sense,' i.e., he did not have a psychosis. But, counsel argued, the expert testimony showed that at the critical moment Murdock did not have control of his conduct, and the reason for that lack of control was a deepseated emotional disorder that was rooted in his 'rotten social background.") (internal citations omitted).

10. Id. at 926 .

11. Id. at 928 .

12. See id. at $928-30$ (reviewing facts of the case).

13. Id. at $959 \mathrm{n.100}$ ("In the language of the closing argument of Murdock's counsel: '[W]hen. . [Murdock] was faced with five whites, with all of his social background, with all of his concepts, rightly or wrongly, as to whether white people were the bogeymen that he considered them to be, the question at this moment is whether he can control himself." ) (internal citations omitted).

14. Richard Delgado, "Rotten Social Background": Should the Criminal Law Recognize a Defense of Severe Environmental Deprivation?, 3 LAW \& INEQ. 9, 54-55 (1985). 
ander would have to show that the overwhelming effect of the RSB was such that we could not reasonably have expected him to have remained law-abiding, that he was blameless for his shooting of the marines.

Indeed, one might go further here and argue that Alexander does not even meet Bazelon's watered-down "product test" requirement, or at least to an extent that any criminal justice system would want to use as a basis for excuse. "Poverty causes crime" is a favorite mantra among some liberals, and it seems a wise crime-control policy that we should shape society to minimize RSBs. ${ }^{15}$ But there is little empirical support for the proposition that a generally impoverished upbringing can itself cause a specific crime so as to render the offender blameless. There may be a general correlation between RSB and crime, ${ }^{16}$ but a general correlation does not make specific causation. ${ }^{17}$

To illustrate the point, consider the strong correlation between being male and committing crime. If correlation did suffice to create an excuse, then the prime candidate for excuse under Bazelon's "product test" would be being male, which has been shown to have an admittedly strong correlation to crime. Chromosomes help determine who we are as people, carrying important genetic material that impacts physical and mental development. Variations in people's chromosomes can contribute to significant differences in behavior. The XY chromosomal pattern of males correlates with criminal and, in particular, violent behavior. (Indeed, it even provides a possible causal story; people born with the condition produce greater quantities of the hormone testosterone that scientists have linked to increased physical aggressiveness.) A person with this chromosomal pattern is nearly four times more likely to commit a criminal offense and more than six times more likely to commit an offense of physical aggression and violence. ${ }^{18}$ Not surprisingly, such persons are dramatically over-

15. See, e.g., U.S. Gov'T ACCOUNTABILITY OFFICE, GAO-07-343T, POVERTY IN AMERICA: CONSEQUENCES FOR INDIVIDUALS AND THE ECONOMY 15-16 (2007) (“[E]vidence suggests a link between poverty and crime."); Pablo Fajnzylber, Daniel Lederman \& Norman Loayza, Inequality and Violent Crime, 45 J.L. \& ECON. 1, 25 (2002) (finding that across countries "the GDP growth rate and the Gini index are the most robust and significant determinants of both homicide and robbery rates.").

16. See Delgado, Rotten Social Background, supra note 14, at 23-37 (reviewing the social science and medical literature on the relationship between rotten social background and crime).

17. Moreover, it is not enough to say that RSBs cause criminal behavior. As Joshua Dressler has noted in attacking the RSB defense, "Causation alone . . cannot be the basis for excusing, for if a person were to be excused whenever his criminal conduct was caused by some factor over which he had no control, all crime would be excusable. All crime, like all other behavior, is an effect of earlier causes." Exegesis of the Law of Duress: Justifying the Excuse and Searching for its Proper Limits, 62 S. CAL. L. REV. 1331, 1380 (1989).

18. Bureau OF Justice Statistics, U.S. DeP'T OF Justice, SPecial Report: Women OFFENDERS 1 (2000), available at http:// bjs.ojp.usdoj.gov/ content/ pub/ pdf/ wo.pdf. One study reported that "[o]ne in every four males living in a large U.S. city can expect to be arrested for [homicide, rape, robbery, aggravated assault, burglary, larceny, or auto theft] some time in his lifetime." Alfred Blumstein \& Elizabeth Graddy, Prevalence and Recidivism in Index Arrests: A Feedback Model, 16 LAW \& SOC'Y REV. 265, 279 (1982). Other studies have roughly confirmed this proportion. 
represented in the prison population. ${ }^{19}$ They make up eighty-four percent of the country's correctional population and are twelve times more likely to be convicted of a violent felony than persons without the pattern ${ }^{20}: \mathrm{sev}-$ enty-eight percent of all arrestees, eighty-four percent of all convicted felons, and eighty-six percent of all violent offenders are male. ${ }^{21}$ The high correlation (and possible causal story) suggest that being male is a significant contributor to criminality generally and violence in particular.

Do we really want to conclude that, given the correlation between being male and committing crime, we should provide a "being male" excuse to crime? A vast number of male offenders can plausibly argue that they would not have committed the offense if they had been born female, so presumably Judge Bazelon's theory would support an excuse for them.

Traditional excuse theory, of course, rejects any such defense. There is little evidence that being male causes substantial cognitive or control dysfunction (although, I know some women might dispute this point). Certainly, there is nothing to suggest a dysfunction so substantial that we cannot reasonably expect a male to remain law-abiding.

In contrast to this overwhelming association of gender with crime rates, social variables that suggest a RSB - growing up in a broken home, inadequate care or child abuse, early socialization to violence and crimehave a much more limited association with higher crime rates. ${ }^{22}$ If we are

See Alex R. Piquero, David P. Farrington \& Alfred Blumstein, The Criminal Career Paradigm, 30 CRIME \& JUST. 359, 419-21 (2003) (reviewing statistical studies on gender and crime). Moreover, "Ir]egardless of the source of data, crime type, level of involvement, or measure of participation, male criminal participation in serious crime at any age is always greater than female participation." Id. at 419. As an example, according to FBI arrest statistics collected by Steffensmeier and Allan from 1990 , only eleven percent of homicide arrestees were female, as were thirteen percent of aggravated assault arrestees, eight percent of robbery arrestees, nine percent of auto theft arrestees, and fourteen percent of drug abuse arrestees. Darrell Steffensmeier \& Emilie Allan, Gender and Crime: Toward a Gendered Theory of Female Offending, 22 ANN. REv. Soc. 459, 461 tbl.1 (1996). Lanctôt and Le Blanc, reviewing the literature, conclude that though "[t]he same mechanisms and processes" explain female criminality as male criminality, "[g]irls . . . have fewer tendencies to get involved in delinquency on a long-term basis; in consequence, their career are shorter and start later." Nadine Lanctôt \& Marc Le Blanc, Explaining Deviance by Adolescent Females, 29 CRIME \& JusT. 113, 115-16 (2002).

19. BUREAU OF JUstice STATISTICS, supra note 18.

20. Id.

21. Id.

22. The criminogenic effects of a RSB remain unclear, in part because RSB remains a vague sociological concept. Still, the literature may be read to suggest that certain variables related to having a RSB, while correlated with criminality, have inconsistent effects on criminality, often having no effect on females (or whites). See, e.g., Beverly Rivera \& Cathy Spatz Widom, Childhood Victimization and Violent Offending, 5 VIOLENCE \& VicTiMs 19, 30 (1990) ("Early childhood victimization demonstrably increases the risk of violent offending through the life span; however, the effects are not distributed similarly across the sexes and races. ... [Adult females who were abused and neglected were not more likely to commit a violent offense than nonabused females. . . For whites, abused and neglected children did not have significantly higher rates of violent arrests than the controls."); Jeffrey R. King, Jens Ludwig, and Lawrence F. Katz, Neighborhood Effects on Crime for Female and Male Youth: Evidence from a Randomized Housing Voucher Experiment, 120 Q.J. ECON. 87, 116 (2005) ( $[\mathrm{u}]$ sing exogenous variation in neighborhood characteristics generated by" a housing voucher pro- 
not prepared to give a defense for "being male," why would we consider giving an excuse for having an RSB?

\section{COERCIVE INDOCTRINATION \& “ROTTEN SOCIAL BACKGROUND” UNDER COERCIVE CRIME CONTROL: DETERRENCE OR INCAPACITATION AS DISTRIBUTIVE PRINCIPLES}

If traditional desert-based excuse theory does not support a CI or an RSB defense, might the also popular crime-control principles of general deterrence or incapacitation?

If general deterrence were the criminal law's distributive principle, ${ }^{23}$ then all of the traditional doctrines of excuse are of questionable value. Their bare existence tends to undermine the clarity and certainty of the deterrent threat, giving potential offenders the hope that they might commit the offense, yet nonetheless escape the threatened punishment. It does not matter that the excuse conditions may prevent the offender at hand from being deterred. (That is a matter of special, not general deterrence. ${ }^{24}$ ) Indeed, rejecting excuse defenses is a wonderful opportunity for the system to advertise and enhance its deterrent threat: it tells the potential offender contemplating an offense that if the system is willing to punish even the blameless offender who deserves excuse, it certainly will not hesitate in punishing him.

It is also the case that for many of the conditions that give rise to excuse, especially those based upon an impairment of control, a rational general deterrence system would want to increase the deterrent threat, not reduce it by recognizing an excuse. If the excusing conditions leave the offender more inclined to commit the offense, the deferent threat ought to

gram, researchers found that "[t]he offer to move to neighborhoods with lower rates of poverty and crime produces reductions in criminal behavior for female youth, but produces mixed effects on the behavior of male youth"); Cesar J. Rebellon, Reconsidering the Broken Homes/Delinquency Relationship and Exploring Its Mediating Mechanism(s), 40 Criminology 103, 125 (2002) (only showing that broken homes are associated with "more than the $10 \%$ to $15 \%$ increase in delinquency that is suggested" by prior research). Benda and Corwyn found that early childhood abuse is a significant variable, but that "the effects of early abuse on violence appear to be overwhelmed by more immediate peer influences among older adolescents." Brent B. Benda \& Robert Flynn Corwyn, The Effect of Abuse in Childhood and in Adolescence on Violence among Adolescents, 33 YOUTH SOC'Y. 339, 358 (2002). Similarly, Widom found that abused and neglected children had higher rates of criminality as an adult, but "[w]hile $29 \%$ of the abused and neglected subjects had adult criminal records, the majority (71\%) did not." Cathy Spatz Widom, Child Abuse, Neglect, and Violent Criminal Behavior, 27 CRIMINOLOGY 251, 266-67 (1989)

23. I have argued elsewhere that it ought not to be, except perhaps in those rare circumstances were its crime-control payoff clearly exceeds its crime-control costs, including its damage to the criminal law's moral credibility and the resulting loss in its normative crime-control power. See PAUL H. Robinson, Distributive Principles of Criminal law: Who Should Be Punished How Much? 73-98, 223-230 (2008).

24. It is only general deterrence that has the powerful attraction as a distributive principle because of its ability, by punishing the offender at hand, to thereby deter thousands or more others gives it enormous power and efficiency, which special deterrence does not share. Id. at 223. 
be cranked up higher to compensate for that greater inclination. (Of course, the argument fails at the point where the offender lacks all control, as in the case of seizure or other entirely involuntary movement, but even there, as noted above, there is crime-control value in punishing the offender as a useful means of sending a clear threat to others.)

If incapacitation of the dangerous were the criminal law's distributive principle, ${ }^{25}$ one would come to a similar conclusion. Where the excusing condition causes the offense-whether it is the mental illness, duress, involuntary intoxication, or immaturity of the traditional excuse defenses, or the more questionable claims of $\mathrm{CI}$ or $\mathrm{RSB}$-an incapacitation principle would want to take control over these offenders, not release them. The stronger the causal contribution to the offense, especially where the causes are known to be continuing, as with $\mathrm{CI}$ or RSB, the stronger the case for preventive detention.

Thus, neither of the standard coercive crime-control distributive principles would have any reason to recognize an excuse defense for CI or RSB.

\section{EMPIRICAL DESERT AS A DISTRIBUTIVE PRINCIPLE: NORMATIVE CRIME CONTROL}

I have argued elsewhere that the criminal law, even if focused on crime control, ought to recognize the importance of being just. Earning greater moral credibility with the community it governs allows criminal law to harness the powerful forces of social and normative influence, and such normative crime control can be as or more effective than coercive crime control. This is true in part because of the potentially strong influence of normative forces in gaining compliance, discussed below, and in part because of the weaknesses in the programs of coercive crime control, which I have discussed elsewhere. ${ }^{26}$

How can the criminal law enhance its moral credibility with the community, and how can this help it influence people's conduct? Let me briefly summarize the arguments that I have made elsewhere. ${ }^{27}$ The law can build its moral credibility by distributing punishment in a way that tracks shared intuitions of justice of the community it governs-what has been called "empirical desert." Empirical desert must be distinguished

25. I have argued elsewhere that it ought never to be, that it makes for more effective preventive detention of society and for greater fairness to detainees to use an openly declared civil preventive detention system, rather than cloaking preventive detention as criminal justice. See id. at 109-10.

26. Id. at 175 .

27. For a fuller account, see id. at 175-212, 223-230; Paul H. Robinson, Geoff P. Goodwin \& Michael O. Reisig, The Disutility of Injustice, 85 N.Y.U. L. REV. 1940 (2010); Paul H. Robinson, Empirical Desert, in CRIMINAL LAW Conversations 29-39 (Paul H. Robinson, Stephen Garvey \& Kimberly Kessler Ferzan, eds., 2009); Paul H. Robinson \& John M. Darley, Intuitions of Justice: Implications for Criminal Law and Justice Policy, 81 S. CAL. L. REv. 1 (2007). 
from what might be called "deontological desert." The latter is derived from the reasoned analysis of moral philosophy; the former is derived from the shared intuitions of justice of the community to be bound by the law. While there is a good deal of overlap between the two, there also are differences. ${ }^{28}$ Empirical desert is not justice in a transcendent sense, as deontological desert is, but only the community's hared view of the principles of justice.

Empirical desert is an attractive distributive principle because by building the moral credibility of the system it can promote cooperation and acquiescence with it, harness the powerful social influences of stigmatization and condemnation, and increase the criminal law's ability to shape societal and internalized norms. (Others have argued that empirical desert is an attractive distributive principle because it promotes democratic ideals or because it is the best approximation of deontological desert that is reasonable to expect in the real world. ${ }^{29}$ )

Some of the system's power to control conduct derives from its potential to stigmatize violators-with some potential offenders this is a more powerful, yet essentially cost-free, control mechanism when compared to imprisonment. Yet, the system's ability to stigmatize depends upon it having moral credibility with the community. That is, for a conviction to trigger community stigmatization, the law must have earned a reputation for following the community's view on what does and does not deserve moral condemnation. Liability and punishment rules that deviate from a community's shared intuitions of justice undermine this reputation.

The effective operation of the criminal justice system depends upon the cooperation, or at least the acquiescence, of those involved in itoffenders, judges, jurors, witnesses, prosecutors, police, and others. To the extent that people see the system as unjust-as in conflict with their intuitions about justice-that acquiescence and cooperation is likely to fade and be replaced with subversion and resistance. Vigilantism may be the most dramatic reaction to a perceived failure of justice, but a host of other

\footnotetext{
28. For example, moral philosophers disagree about the significance of resulting harm and each side of the debate has plausible arguments to make. In contrast, all available data suggest a nearly universal and deeply held view among laypersons that resulting harm does matter. The absence of a resulting harm or evil reduces the actor's blameworthiness; the presence increases it. Thus, the two alternative distributive principles disagree about whether resulting harm should even be an element of an offense definition, whether it should affect an offense's grade, and whether completed offenses should be punished more than unsuccessful or interrupted attempts. This is only one of a host of issues on which moral philosophy's analytic conclusions are likely to vary from the empirical data on lay persons' intuitions of justice. For community views on a variety of criminal law issues that may conflict with moral philosophers' views, see generally Paul H. Robinson, The Role of Moral Philosophers in the Competition Between Deontological and Empirical Desert, 48 WM. \& MARY L. REV. 1831 (2007).

29. See, e.g., Andrew E. Taslitz, Empirical Desert: The Yin and Yang of Criminal Justice, in Criminal LaW Conversations, supra note 27, at 56; Adil Ahmad Haque, Legitimacy as Strategy, in CRIMINAL LAW CONVERSATIONS, supra note 27, at 57.
} 
less dramatic (but more common) forms of resistance and subversion have shown themselves. Jurors may disregard their jury instructions. Police officers, prosecutors, and judges may make up their own rules. Witnesses may lose an incentive to offer their information or testimony. And offenders may be inspired to fight the adjudication and correctional processes rather than participating and acquiescing in them.

Criminal law also can have effect in gaining compliance with its commands through another mechanism: If it earns a reputation as a reliable statement of what the community perceives as condemnable, people are more likely to defer to its commands as morally authoritative and as appropriate to follow in those borderline cases in which the propriety of certain conduct is unsettled or ambiguous in the mind of the actor. The importance of this role should not be underestimated; in a society with the complex interdependencies that characterize ours, a seemingly-harmless action can have destructive consequences. When the action is criminalized by the legal system, one would want the citizen to respect the law in such an instance, even though he or she does not immediately intuit why that action is banned. Such deference will be facilitated if citizens believe that the law is an accurate guide to appropriate prudential and moral behavior.

Perhaps the greatest utility of empirical desert comes through a more subtle but potentially more influential mechanism. The real power to gain compliance with society's rules of prescribed conduct lies not in the threat of official criminal sanction, but in the influence of the intertwined forces of social and individual moral control. The networks of interpersonal relationships in which people find themselves, the social norms and prohibitions shared among those relationships and transmitted through those social networks, and the internalized representations of those norms and moral precepts control people's conduct. The law is not irrelevant to these social and personal forces. Criminal law, in particular, plays a central role in creating and maintaining the social consensus necessary for sustaining moral norms. In fact, in a society as diverse as ours, the criminal law may be the only society-wide mechanism that transcends cultural and ethnic differences. Thus, the criminal law's most important real-world effect may be its ability to assist in the building, shaping, and maintaining of these norms and moral principles. It can contribute to and harness the compliance-producing power of interpersonal relationships and personal morality, but will only be effective in doing so if it has sufficient credibility.

The extent of the criminal law's effectiveness in all these respects-in bringing the power of stigmatization to bear, in avoiding resistance and subversion to a system perceived as unjust, in gaining compliance in borderline cases through deference to its moral authority, and in facilitating, communicating, and maintaining societal consensus on what is and is not condemnable - is to a great extent dependent on the degree to which the criminal law has gained moral credibility in the minds of the citizens gov- 
erned by it. Thus, the criminal law's moral credibility is essential to effective crime control, and is enhanced if the distribution of criminal liability is perceived as "doing justice" - that is, if it assigns liability and punishment in ways that the community perceives as consistent with its shared intuitions of justice. Conversely, the system's moral credibility, and therefore its crime-control effectiveness, is undermined by a distribution of liability that conflicts with community perceptions of just desert.

Confirming the findings of previous studies, ${ }^{30}$ the most recent set of studies show that many modern crime-control doctrines seriously conflict with the community's shared intuitions of justice, that this conflict does indeed undermine the criminal law's moral credibility, and that this loss does indeed have practical consequences that undermine the criminal justice system's crime fighting effectiveness. ${ }^{31}$

\section{COERCIVE INDOCTRINATION UNDER NORMATIVE CRIME CONTROL: THE CASE OF POW RICHARD TENNESON}

If empirical desert were one's distributive principle, should CI or RSB be a defense? There is some evidence to suggest lay support for some kind of excuse defense in some such cases. Consider that of Richard Tenneson. ${ }^{32}$ He grew up on a farm in rural Minnesota. ${ }^{33}$ Though he never left his home state, he was deeply patriotic, and at the outbreak of the Korean War the seventeen-year old did not hesitate to quit high school and enlist to fight overseas. ${ }^{34}$ During his visit home after basic training he told his mother, "If I should win the Congressional Medal of Honor, I still wouldn't have done enough for my country." ${ }^{35}$ Within months he was on the front line in Korea with the 2nd Army Division, south of the 38th parallel. ${ }^{36}$ The Communist Chinese were in the midst of a spring offensive that pushed the 2nd Division back toward Seoul, and cut it off from the main body of American forces. ${ }^{37}$ Communist forces overran Tenneson's position and took him prisoner, along with hundreds of others. ${ }^{38}$ During the next five months, Tenneson and the other prisoners were marched north. ${ }^{39}$ More than half died of starvation before the march ends three

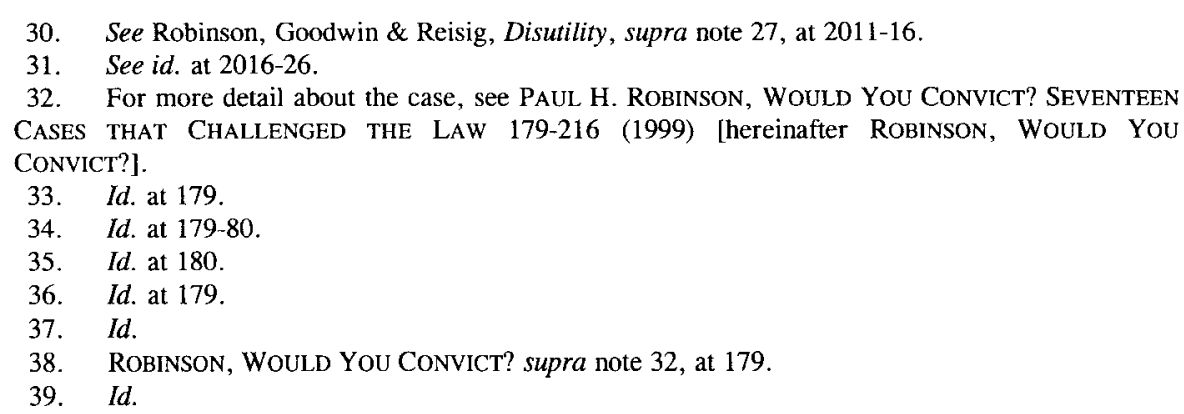


hundred miles north, at a prison camp on the Yalu River near Chungsong. ${ }^{40}$

A few weeks after reaching the camp, Tenneson was removed from the general population; his captors said he was being hospitalized for pneumonia. ${ }^{41}$ When Tenneson emerged from his "hospital" stay, his world view had changed. ${ }^{42}$ He was now a devoted believer in the Communist Chinese cause. ${ }^{43}$ Tenneson made propaganda broadcasts for his captors and worked to promote their cause among the prisoners. ${ }^{44}$ A few months later Tenneson, then eighteen, formally renounced his United States citizenship and defected to Communist China. ${ }^{45}$ In December 1953, when the Korean hostilities ceased, Tenneson joined twenty other POWs who refused repatriation to the United States and elected to stay with their former captors. ${ }^{46}$

In the aftermath of the revolution in China, the Communists developed considerable expertise in coercive indoctrination. ${ }^{47}$ Their methods have been studied by Westerners and their effectiveness proven. ${ }^{48}$ Rather than mere physical torture, the indoctrination techniques follow a series of stages in which the subject is first isolated, then disoriented, through malnutrition and constant provocation of anxiety, and finally made to participate in symbolic acts of self-betrayal. ${ }^{49}$ This renders the subject's previous personality subject to degradation. ${ }^{50}$ The captors then build up a new personality, one that agrees with the belief structure of the indoctrinators, by offering positive reinforcement when the subject expresses the desired views. ${ }^{51}$ Eventually, the subject does not feel manipulated and comes to truly hold the beliefs of his captors. ${ }^{52}$

Two years after hostilities with Korea end, the Communists have little use for Tenneson, his value as an instrument of propaganda having run its course. ${ }^{53}$ He was given a farming job and left to his own devices. ${ }^{54}$ To fully maintain the effectiveness of coercive indoctrination, however, the belief structure must be regularly reaffirmed in the subject. Without continued reinforcement, Tenneson became homesick and eventually arranged

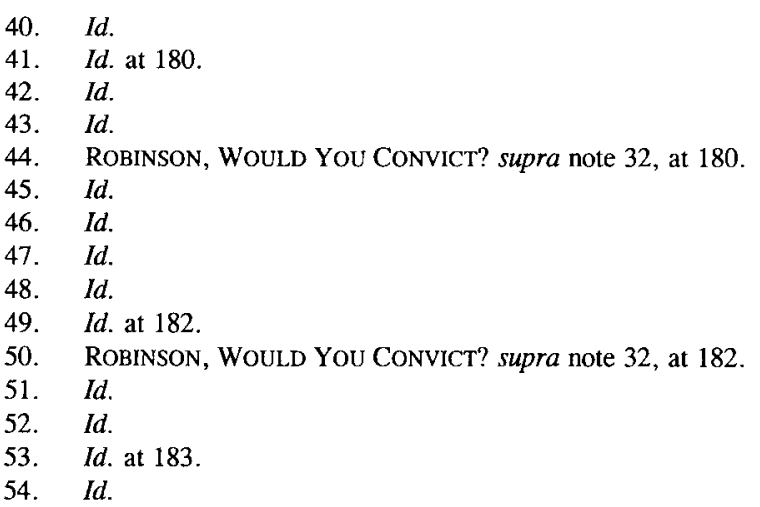


to be repatriated to the United States. ${ }^{55}$ On his return, he was arrested for treason. ${ }^{56}$ While he initially expressed some sympathy for his former captors, before too long he renounced their Communist ideology, ultimately becoming quite bitter toward his former captors for what he thought they had done to him. ${ }^{57}$

At the time, there was strong public support for the POWs like Tenneson who were seen as being "brainwashed" into becoming collaborators, even though aiding the enemy in a time of war was seen as an extremely serious offense. The Department of Justice adopted a policy of refusing to prosecute such cases. ${ }^{58}$ The Department of the Army, in contrast, did prosecute such cases, but its policy triggered public protests, to the point where Army prosecutors were forced to carry sidearms to court and to slip out the back door after court sessions. ${ }^{59}$

The support was not simply a product of the special war-time atmosphere. Even today, there is much sympathy for Tenneson. For more than a decade I and other criminal law teachers have been asking first year criminal law students to "sentence" Tenneson after reading the facts above. These are their cumulative responses: ${ }^{60}$

\footnotetext{
55. Id. at 184 .

56. ROBINSON, WOULD YOU CONVICT? supra note 32, at 184.

57. Id.

58. Id. at 188. The Department of Justice knew that collaboration was widespread among American prisoners who were coercively indoctrinated. Even many of the prospective witnesses who the prosecutors would rely on engaged in some collaboration activities. The Department also concluded that the servicemen had not been adequately prepared for capture and indoctrination. Perhaps most importantly, the Department feared that any large-scale prosecution would be difficult to win and politically unpopular. The evidence of coercive indoctrination that few could resist would create a natural sympathy among jurors, who would be reluctant to convict the defendants on such a serious charge as treason. Id.

59. Id. at 186-87. In the Army view at the time, whatever the extent of the "traitor" POW's blameworthiness or lack thereof, the law was the law. The law does not recognize a defense or mitigation for coercive indoctrination, and therefore neither would the Army. Many former POWs claiming coercive indoctrination were convicted. Prison terms commonly ranged between eight years and twenty years; some got life imprisonment. But a U.S. Supreme Court decision coming in the midst of the Army prosecutions held that only the Department of Justice, not the Army, could prosecute soldiers no longer in the service, which amounted to about half of the three thousand eligible for prosecution.

60. Paul H. Robinson, Teacher's manual for Criminal Law: Case Studies \& CONTROVERSIES 89 (2d ed. 2008).
} 


\begin{tabular}{|c|c|c|c|c|c|c|c|c|c|c|c|c|}
\hline $58 \%$ & $21 \%$ & $1 \%$ & $1 \%$ & - & $3 \%$ & $5 \%$ & $5 \%$ & $4 \%$ & $1 \%$ & - & $1 \%$ & - \\
\hline $\begin{array}{c}\text { No } \\
\text { liability }\end{array}$ & $\begin{array}{c}\text { liability } \\
\text { but po } \\
\text { punishment }\end{array}$ & 1 day & 2 wks. & $2 \mathrm{mo}$. & $6 \mathrm{mo}$. & $1 \mathrm{yr}$. & $3 \mathrm{yrs}$ & $7 \mathrm{yrs}$ & $15 \mathrm{yrs}$ & $30 \mathrm{yrs}$ & $\begin{array}{c}\text { Life } \\
\text { imprisonment }\end{array}$ & death \\
\hline
\end{tabular}

Mean $=3.6$ days

Seventy-nine percent of the people in the survey impose either no liability or no punishment. ${ }^{61}$ Only thirteen percent impose a sentence of over a year. ${ }^{62}$ For the serious offenses charged, this suggests that the vast majority, eighty-seven percent, think a significant mitigation appropriate, if not a complete excuse. ${ }^{63}$

If coercive indoctrination renders a Richard Tenneson blameless for conduct induced by the indoctrination, ought not the criminal law take notice? Certainly if one were to adopt empirical desert as one's distributive principle for criminal liability and punishment, then such lay intuitive support suggests that a $\mathrm{CI}$ excuse ought to be seriously considered. But despite the public support, no court has ever recognized a defense for coercive indoctrination. ${ }^{64}$ (Patty Hearst, for example, when kidnaped by the Symbionese Liberation Army, was held liable for crimes she committed while supposedly transformed by the SLA into the revolutionary "Tanya." ${ }^{65}$ Given the evidence of the power of coercive indoctrination, why such resistance in law to recognizing a defense?

Perhaps the concern is that, while cases like Tenneson ought to be excused, others, perhaps Hearst, ought not, because they simply are not sufficiently compelling to produce the same intuitive conclusion of blamelessness. But the proper response to that concern is not to reject a CI excuse entirely, for such an approach assures the conviction of some blameless offenders, like Tenneson, a result that would incrementally undermine the moral credibility of the criminal law. Enhancing criminal law's moral credibility with the community it governs requires an attempt to dissect the intuitions that support the excuse and to fashion an excuse formulation that limits the defense to the situations that prompt conclusions of blamelessness.

To do this properly would require an empirical study that maps the contours of lay intuitive support and constructs the defense formulation that best captures those lay intuitions of justice in CI cases. Without such research, one can only speculate, using one's own intuitions and perhaps

\footnotetext{
61. Id.

62. Id.

63. Id.

64. Rebecca Emory, Losing Your Head in the Washer-Why the Brainwashing Defense Can Be a Complete Defense in Criminal Cases, 30 PACE L. REv. 1337, 1338 (2010) (noting that "[t]he brainwashing defense has not yet been successful" in any jurisdiction).

65. ROBINSON supra note 32 , at 186-87.
} 
extrapolations from related studies. ${ }^{66}$ If one were to make such a rough guess at what drives people's intuitions in such cases, one might construct as a starting point a $\mathrm{CI}$ excuse formulation that looked something like this:

An actor is excused for his conduct constituting an offense if:

(1) he was coerced to adopt beliefs and values that were not his own

(2) by influences sufficiently strong that he could not reasonably have been expected at have resisted their effect, given his abilities and situation; and

(3) the nature of the coerced beliefs and values were such as to demand the offense; and

(4) the actor would not have committed the offense had he not been coercively indoctrinated with those beliefs and values, and could not reasonably have been expected to have avoided committing the offense.

Such a formulation might well give a defense to Tenneson but perhaps not, depending upon the exact facts, to Hearst or in other cases. The following Part examines what challenges one might encounter in trying to distinguish Tenneson from other cases that might arguably be seen as potentially eligible for a CI or an RSB excuse.

\section{TESTING THE LIMITS OF A COERCIVE INDOCTRINATION OR A "ROTTEN Social BACKGRound" EXCUSE: The CASE of Alex CABARGa}

If the law were to recognize a CI excuse for Tenneson, how far beyond Tenneson should it extend? And should it extent to RSB cases, where the indoctrination effect could be as powerful but is less an explicit "indoctrination program" and more simply the daily influence of a horribly difficult life? Consider, for example, the case of Alex Cabarga, who had a seriously rotten social background. ${ }^{67}$ When Cabarga was five, his parents gave up their traditional life and moved to an "experimental community" named Project Two, which was located in a vacant warehouse. ${ }^{68}$ Several weeks after the family's arrival, a thirty-three-year old man named Luis "Tree Frog" Johnson joined the group. ${ }^{69}$ He was a transient who shared the group's goals of throwing off old taboos. ${ }^{70}$ He especially favored complete freedom for children. ${ }^{71}$ Tree Frog befriended five-year old Alex and his two older brothers, and the boys began spending their days with him. ${ }^{72}$ The parents did not like Tree Frog but allowed him un-

\footnotetext{
66. Also informing this speculation are a few decades of hearing law students express their views on the $\mathrm{CI}$ and RSB cases discussed here.

67. For more detail, see RoBinson, WOULD You ConviCT?, supra note 32, at 191-205

68. Id. at 191

69. Id.

70. Id.

71. Id.

72. II.
} 
fettered access to their children, adopting the open-mindedness that their new lifestyle called for. ${ }^{73}$

Two years later, Alex's parents separated. ${ }^{74}$ His mother took legal custody of the boys and moved to a trailer near the warehouse. ${ }^{75}$ Tree Frog lived in an old school bus on the same property and continued his relationship with the boys. ${ }^{76}$ Tree Frog courted seven-year old Alex as he would have a sexual partner. ${ }^{77}$ As Alex's older brothers grew older, they moved out of the trailer and broke contact with Tree Frog. ${ }^{78}$ Alex's mother suspected that Tree Frog had been having sex with Alex for some time but did nothing about it. ${ }^{79}$ When Alex was nine, his mother essentially handed over parental custody to Tree Frog, and Alex moved in with him. ${ }^{80}$ His mother explained later that she was simply tired of being a parent. ${ }^{81}$

After he gained custody, Tree Frog's physical and sexual abuse of Alex became regular. ${ }^{82}$ He hit Alex and denied him food if Alex resisted having sex or otherwise disobeyed. ${ }^{83}$ Tree Frog and Alex moved away from the warehouse community. ${ }^{84}$ They lived a nomadic life in a dilapidated bread van with cardboard on the windows, moving the van from one seedy San Francisco neighborhood to another. ${ }^{85}$ For money, Tree Frog sold pornographic movies of Alex. ${ }^{86}$ Tree Frog believed in a radical dogma that advocated open sexual relations between adults and children and argued that even a very young girl could conceive a child. ${ }^{87}$ Tree Frog decided that they would kidnap a little girl and raise her according to his radical tenets, including having her conceive Tree Frog's child, who then also would be so raised. ${ }^{88}$

Alex, now seventeen, helped Tree Frog kidnap a $2 \frac{1}{2}$ year old girl named Tara Burke from her parents' van in an auto supply store parking lot. ${ }^{89}$ Tree Frog treated Tara as he had treated Alex after gaining custody. ${ }^{90}$ She was denied food unless she obeyed directions, which included

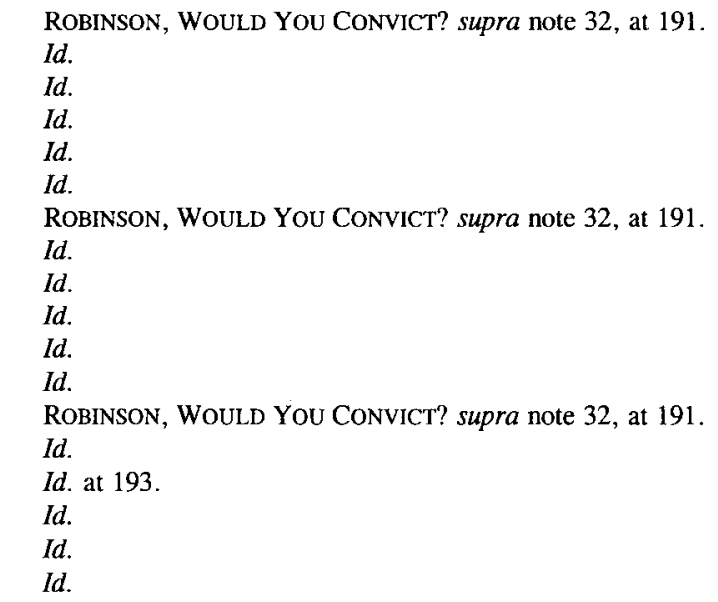


having sex with Tree Frog and Alex. ${ }^{91}$ Tree Frog took pictures and sometimes movies of Alex and Tara having sex. ${ }^{92}$ Tara was not allowed to wash and was kept naked from the waist down. ${ }^{93}$ Her once blond hair became dirty brown. Tree Frog soon cropped it close to her head. ${ }^{94}$ Two months later, an eleven-year-old Vietnamese runaway, Mac Lin Nguyen, was befriended by Tree Frog and offered $\$ 200$ to babysit Tara. ${ }^{95} \mathrm{He}$ moved into the van to live with the group. ${ }^{96}$ He was treated as Alex had been, originally courted, then, once isolated and dependent, increasingly made Tree Frog's subject of abuse. ${ }^{97}$ Tree Frog continued his practice of taking pictures and movies as he directed sex between the children. ${ }^{98}$ After eight months, Mac left and reported the activities in the van to the police. ${ }^{99}$ Police found Alex and Tara under blankets, both naked from the waist down. ${ }^{100}$ When Tara was reunited with her parents, they did not recognize her. She had an extensive vocabulary, including all the most vulgar words imaginable. ${ }^{101}$ A therapist later concluded that her ten-month ordeal had scarred her for life. ${ }^{102}$

Alex's case has some similarities to Richard Tenneson's, but also some significant differences. Alex was never a prisoner as Richard was. On the other hand, Alex was a psychological captive of Tree Frog, especially after Tree Frog took parental custody. Indeed, nine-year-old Alex was considerably younger and more vulnerable when given to Tree Frog than was seventeen-year-old Richard when he became a POW.

Alex's greater vulnerability was effectively exploited by Tree Frog. Note the similarity between Tree Frog's treatment of Alex and the Communist captors' coercive indoctrination of Richard. Tree Frog created isolation and control by living in a bread van from which there was no escape from his constant attention, and a nomadic existence that prevented Alex from developing relationships with persons other than Tree Frog. In other words, Tree Frog's program followed many of the standard elements of the first phase of coercive indoctrination: physiological debilitation through reduced food, which served in addition as a means of control, and creation of constant background anxiety through the constant fear of abuse and denial of food.

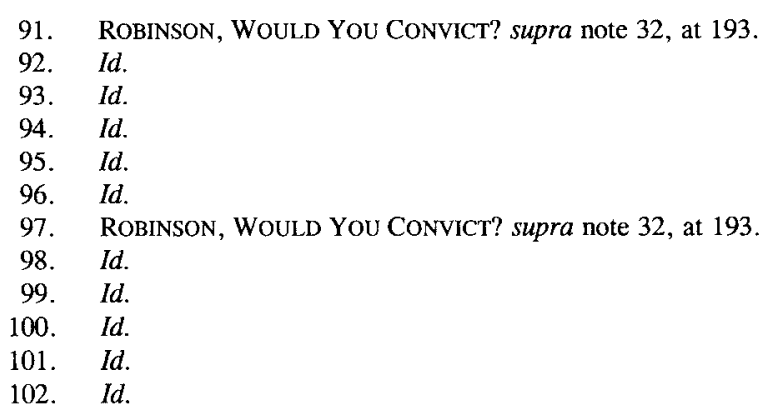


There was little need for the other elements of the indoctrination scheme-the degradation of Alex's pre-existing self and the required performance of symbolic acts of self-betrayal, betrayal of group norms, and confession. At age nine, Alex had little pre-existing self established, and that which did exist had internalized the counterculture norms of his parents and their social group that the violation of traditional norms was a virtue.

POW Richard, at seventeen, at least had the chance to develop something of a self, an independent self that had internalized norms he could try to use as an anchor against the current of coercive indoctrination. What was Alex's anchor? The teachings of parents who preached communal sex, including a tolerance of child sex? His pre-existing self derived from the moral lessons of parents who turned him over to Tree Frog knowing that Tree Frog was sexually abusing him? Alex's internalized norms from childhood-"right-thinking people reject the old conventions"-were no anchor. They were part of the current. One might conclude that Alex's values and conduct were as induced and manipulated by Tree Frog as were Richard's by his Communist captors.

Would Alex qualify for a coercive indoctrination defense under the formulation set out above? Cabarga does seem to have been indoctrinated by beliefs and values that were not his own, as required by (1). And it seems clear that Alex would not have committed the offenses but for Tree Frog's (and his parent's) indoctrination, and, given his age and situation, it might not have been reasonable to expect him to have resisted, satisfying (4). Further, Tree Frog's indoctrination was indeed focused on committing just those offenses with which Cabarga is charged, the requirement in (3). Finally, one might conclude that the younger, more vulnerable Alex could not reasonably have been expected to have resisted Tree Frog's indoctrination any more than POW Richard could have been expected to have resisted his captors', as (2) requires.

If there is some suspicion on this last point, or point (4), it is that as Alex grew older, at seventeen or sixteen or earlier, he should have had the strength of character to see the wrongfulness of what he was doing and to break off from Tree Frog. But that assumes Alex had some internal normative conflict over what he was doing, which only brings us back to the lack-of-anchor problem. Certainly most seventeen year olds would be repulsed by the conduct. And clearly Alex knew that what he was doing was wrong, at least in the sense that he knew society strongly disapproved of it. After all, he and Tree Frog actively hid what they did. But, in Alex's upbringing, that social disapproval meant that it was the "rightthinking" thing to do.

But still, Alex must have known it was wrong in a deeper moral sense. $\mathrm{He}$, better than anyone, knew how it felt to be the object of such manipulation and abuse from Tree Frog. Better than anyone, he understand what 
Tara and Mac endured. On the other hand, Alex had chosen to stay with Tree Frog despite the abuse (as did Mac for a time, although he had none of the Alex's history of parental collusion and indoctrination).

It is a complex dynamic at work. Abused children often abuse their own children. Fraternity pledges often willingly endure abuse to become a member (and in turn abuse the members of the next year's pledge class). Army recruits, like Richard, volunteer for the abuse of boot camp (and may well aspire to become abusing drill instructors themselves). Knowing the sting of abuse does not always give an understanding of how wrong it is; it sometimes seems only to devalue its wrongfulness, to desensitize the abused to the wrongfulness of abuse.

Could we reasonably have expected Alex to have resisted Tree Frog's indoctrination? To have spontaneously walked away to start a new life for himself? People will disagree on this; it is not entirely clear. But it seems clear that, in judging Alex, the law cannot retain moral credibility if it ignores the indoctrination that brought Alex to the offenses.

Here is how the first year law students sentenced Alex Cabarga: ${ }^{103}$

\begin{tabular}{|c|c|c|c|c|c|c|c|c|c|c|c|c|}
\hline $26 \%$ & $29 \%$ & - & - & $1 \%$ & $1 \%$ & $3 \%$ & $5 \%$ & $5 \%$ & $4 \%$ & $2 \%$ & $2 \%$ & $19 \%$ \\
\hline no liability & $\begin{array}{c}\text { liability } \\
\text { but no punishment }\end{array}$ & 11 day & 2 wks. & 2 mo. & 6 mo. & 1 yr. & 3 yrs. & 7 yrs. & 15 yrs. & 30 yrs. & $\begin{array}{c}\text { Life } \\
\text { imprisonment }\end{array}$ & $* *$ \\
\hline
\end{tabular}

** no punishment, but civil preventive

detention for as long as he is dangerous

Mean $=10.1$ days

In the survey, over half of the people impose either no liability or no punishment. ${ }^{104}$ Only eighteen percent impose a sentence of three years imprisonment or more. ${ }^{105}$ Even among those who impose imprisonment, however, the terms are dramatically less than one might expect for such a collection of serious offenses; only eight percent suggest prison terms of fifteen years or more. ${ }^{106}$ (About a fifth of the people surveyed would subject Cabarga to detention for as long as he is dangerous, but would not impose criminal liability.) ${ }^{107}$ Apparently Alex's history does serve as a substantial mitigation to most people and as a complete excuse from punishment for a majority (fifty-five percent). ${ }^{108}$

Alex in fact was charged by prosecutors with the same range of offenses as Tree Frog. ${ }^{109}$ At trial, the prosecution case was based primarily

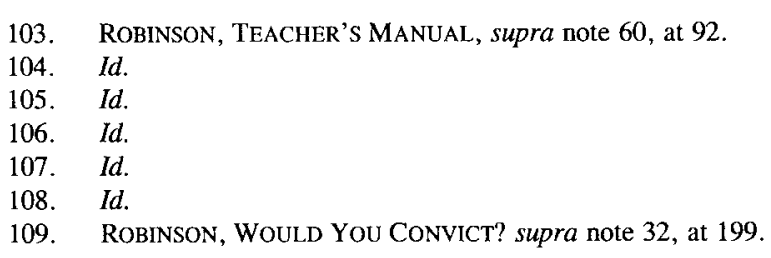


on the pictures and movies taken by Tree Frog. ${ }^{110}$ The law had not changed since Richard Tenneson's time two decades before. Coercive indoctrination was neither a defense nor a mitigation. Alex was convicted of all offenses and sentenced to 208 years in prison. ${ }^{11}$ (At the same time, the board of the California Victims of Crime Program concluded that Alex was a victim of Tree Frog's abuse, found Alex eligible for aid under the Program, and agreed to pay $\$ 10,000$ toward his psychiatric counseling, the same amount that victim Tara received.) $)^{112}$

\section{VI. “ROTTEN SOCIAL BACKGROUND” \& EMPIRICAL DESERT}

Tenneson is a classic CI case. Cabarga is a somewhat atypical CI case, resting as it does more on a horrible RSB than on a formal indoctrination program, but a case that seems plausibly analogous to CI. The strength of the analogy between the two cases illustrates the potential strength of the analogy between CI and RSB generally. That is, once one goes beyond the official indoctrination program in Tenneson to the less formal indoctrination effect that occurred in Cabarga, it seems hard to exclude from the analogy any other influential factor that shapes beliefs and values, no matter whether it was formal or informal, intended or accidental, whether it was the product of one person or group or an entire society, or whether it was executed in a bread truck or on the mean streets. That is, if we have sympathy for Tenneson and Cabarga, we ought to have similar sympathy for any offender who can show he has been similarly coercively and involuntarily indoctrinated into committing an offense.

Yet simple RSB-that is, the influence of a terribly difficult life of privation and violence but without an identifiable protagonist, like a Tree

\footnotetext{
110. Id.

111. Id.

112. Id. Some time later, however, upon recommendation of the district attorney, Alex's sentence was reduced to twenty-five years in prison. As of today, Tree Frog Johnson remains in prison, serving a 527-year sentence. Id. at 204. Alex Cabarga was paroled in 1995, having served eleven years of his twenty-five-year reduced sentence. Id.

In the end, then, the district attorney and judge saw Alex as very different from Tree Frog, who gets no reduction. Alex's ultimate mitigation was not nearly the reduction that the people in the survey would have provided, but nonetheless was significant. On the other hand, twenty-five years is still a substantial prison term. Note, however, that even this degree of mitigation depended on the exercise of prosecutorial discretion. The law gives Alex no right to a mitigation or reduction. One easily can imagine slightly different circumstances in which a different result would have occurred. A different person as prosecutor might have had a different view of the case. A prosecutor (or judge) in a tough re-election bid or seeking a different office, might have been more afraid of being viewed as soft on a child abuse.

As with the disposition of POW's in Richard's case, we may ask whether Alex's punishment ought to depend in this way on the characteristics and circumstances of the prosecutor rather than on the characteristics and circumstances of the offense and offender? Ought not the legal rules themselves recognize and control a defense or mitigation, according to whether a jury is persuaded that the circumstances warrant it?
} 
Frog, who is attempting to manipulate the defendant-does not have the intuitive sympathy offered a Cabarga, let alone the strong support offered a Tenneson. ${ }^{13}$ What might explain the lack of support for an excuse for a "simple RSB," as it might be called?

One difficulty may be skepticism about whether one's general environment alone is so overwhelming as to undermine one's normal ability to shape one's own beliefs and values. Many people-including people with RSBs-will point out the obvious: that the vast majority of people with RSBs do not become criminals. ${ }^{114}$ That so many with RSBs internalize appropriate norms would seem to suggest that the power of the indoctrination is something less than overwhelming. On the other hand, most prisoners in Tenneson's situation did not betray their country by adopting the ideology of the enemy, yet Tenneson gets sympathetic support.

Part of the skepticism about an excuse for simple RSB may stem from a judgment that the kinds of beliefs and values with which one is indoctrinated by RSB are not beliefs and values that themselves compel lawbreaking, in the way that Tenneson's captors or Cabarga's custodian shaped their indoctrination to achieve the specific goal of engaging in conduct that was an offense. That is, an RSB may have a serious influence on beliefs and values but those beliefs and values do not seem to clearly lead to criminality, such as the shooting of insufficiently respectful marines, as occurs in Alexander. ${ }^{115}$ Alexander may well be a different person than he otherwise would have been if he had not had an RSB, but it is hard to see how that RSB compels his killings. What may seem more plausible to people is that his offense conduct was as much a product of his own selfishness, arrogance, and pride as it was a product of anything his RSB created in him. (Note that Alexander would not seem to satisfy the requirements of the CI defense proposed above.)

A different sort of skepticism may arise from the implications of giving Alexander an excuse. There is an enormous lay intuitive commitment to the notion that people normally operate with free will, that people are generally responsible for who they are. ${ }^{116}$ It is this foundation that sup-

113. For example, after Tenneson and Cabarga, the first year students "sentenced" a third case, of Robert Sandifer. Indeed, Sandifer has the advantage of claiming a traditional immaturity excuse, beyond any RSB claim. Yet the responses on Sandifer are noticeably less sympathetic than even for Cabarga. See ROBINSON, TEACHER'S MANUAL, supra note 60, at 94.

\begin{tabular}{|c|c|c|c|c|c|c|c|c|c|c|c|c|}
\hline $3 \%$ & $4 \%$ & - & - & - & $1 \%$ & - & $1 \%$ & $13 \%$ & $25 \%$ & $19 \%$ & $28 \%$ & $6 \%$ \\
\hline mo liability & $\begin{array}{c}\text { liability } \\
\text { but no punishment }\end{array}$ & 1 day & 2 wks. & $2 \mathrm{mo}$. & $6 \mathrm{mo}$ & $1 \mathrm{yr}$. & 3 yrs. & 7 yrs. & 15 yrs. & 30 yrs. & $\begin{array}{c}\text { Life } \\
\text { imprisonment }\end{array}$ & death \\
\hline
\end{tabular}

Mean $=18.4$ years

114. See sources collected at supra note 22 .

115. 471 F.2d at 959.

116. See Eddy Nahmias et al., Surveying Freedom: Folk Intuitions about Free Will and Moral 
ports the essentially universal human intuition that serious wrongdoing deserves punishment. ${ }^{117}$ Cases like Tenneson do not seriously threaten this conception of people's accountability for who they are. The circumstances of Tenneson's "brainwashing," as it was called back then, were so unusual and so apart from the nature of people's daily lives that they could easily shift the blame for the offense to the effects of having been "brainwashed." Giving an excuse to Tenneson seems to have few implications for offenders other than prisoners subjected to official indoctrination programs.

In this respect, even the Cabarga case raises some suspicion, although it might be tolerable. While Cabarga's situation is quite bizarre and not likely to be replicated, his case does illustrate a certain ambiguity as to where the line should be drawn, for the case is not qualitatively different from the many other difficult life situations in which we know many people suffer. As sad as it is, Cabarga's "social background" is just the extreme of a genre of bad situations in which people are raised. A bread truck is not a prison camp, and a twisted hippie's malevolent teachings are not an enemy's indoctrination program. Tenneson does seem to have had an experience that is qualitatively different from our daily lives, while Cabarga might be seen as having had one that was only quantitatively different, albeit an extreme. It is perhaps for this reason that people's intuitions are somewhat less sympathetic for Cabarga than for Tenneson.

By these measures, one would expect little if any intuitive support for Alexander or any other simple RSB offenders. A rotten social background is likely to be seen as the tragic reality of many people's unfortunate life. As bad as such a life may be, it is only quantitatively different from the struggles, disappointments, temptations, deprivations, and outrages that most people experience in their daily lives. It is worse, but it is not qualitatively worse. If the base intuitive assumption is that people are responsible for who they are, then the circumstances of a simple rotten social background itself may not be so unique as to override than intuitive assumption.

\section{SUMMARY AND CONCLUSION}

Part I explains why traditional desert-based excuse theory roundly rejects defenses for both CI and RSB. The offender lacks any cognitive or control dysfunction at the time of the offense. Even if a prior coercive

Responsibility, 18 PHIL. PSYCHOL. 561, 571 (2005) (finding lay support for the philosophical concepts of compatibilism and free will based on a series of surveys).

117. See Paul H. Robinson \& Robert Kurzban, Concordance and Conflict in Intuitions of Justice, 91 MINN. L. REV.1829, 1872 (2007) (finding empirical support for the proposition that people almost universally believe that serious wrongdoing should be punished). 
indoctrination were viewed as somehow a substitute for the traditionallyrequired dysfunction, the extent of its effects generally would not be so severe as to compel a conclusion of blamelessness. Even a "but for" cause of the crime is insufficient under the traditional excuse theory, and a simple RSB can hardly show even that level of effect.

Part II examines how a CI or RSB excuse would fare under the standard coercive crime-control strategies of optimizing general deterrence or incapacitation of the dangerous. Those distributive principles come to a similar result of rejecting such defenses. Their recognition as a defense would tend to undermine deterrence and incapacitation goals.

This is not necessarily the end of the story, however. Part IV describes the coercive indoctrination case of POW Richard Tenneson, which prompted considerable public sympathy, confirming that lay persons tend to exculpate some CI offenders. And as Part III explains, such intuitive support for a coercive indoctrination defense suggests that there may be important practical crime-control value in having criminal law recognize the defense. If the criminal law can build its reputation as a reliable moral authority with the community it governs, it can harness the potentially powerful forces of social and normative influence.

Finally, as the Cabarga case in Part V illustrates, there are good arguments for seeing a "rotten social background" as a form of coercive indoctrination and, thus, for considering it too for a defense under such a newly-created doctrine. However, while some RSB cases may qualify as CI cases, simply having a "rotten social background" by itself is not likely to meet the minimum requirements that even the most sympathetic society logically would place upon a coercive indoctrination excuse. A CI defense might support an excuse in some cases in which an RSB is the main component, as in Cabarga, but a simple RSB, without more, is unlikely to qualify for a defense under any of the modern theories of punishment. 